\title{
Mma Exercises in Physical Education of 17-18-Year-Old Students
}

\section{Ejercicios de Mma en Educación Física para estudiantes de 17-18 años}

\section{TODOROVA VALENTYNA GEORGIEVNA}

The State institution «South Ukrainian National Pedagogical University named after

K. D. Ushynsky», Odesa, Ukraine

ORCID ID: 0000-0002-3240-6983

PETRO FEDOROVICH RYBALKO

Sumy Makarenko State Pedagogical University, Sumy, Ukraine ORCID ID: 0000-0002-6460-4255

OKSANA YAKIVNA DUBYNSKA

Sumy Makarenko State Pedagogical University, Sumy, Ukraine ORCID ID: 0000-0001-7088-3484

OLEKSANDR SERHIYOVICH KHOMENKO

Sumy National Agrarian University, Sumy, UKRAINE ORCID ID: 0000-0001-7509-9787

GVOZDETSKA SVITLANA VOLODYMYRIVNA

Sumy Makarenko State Pedagogical University, Sumy, Ukraine ORCID ID; 0000-0002-7744-7471

ANDRII DMYTROVICH KRASILOV

Sumy Makarenko State Pedagogical University, Sumy, Ukraine ORCID ID: 0000-0001-6167-3151

\section{YEVTUSHENKO YEVHEN HRYHOROVYCH}

Candidate of Sciences in Pedagogy, Senior Lecturer in the Department of physical education of the Sumy National Agrarian University ORCID ID: 0000-0003-1036-4652

* Correspondence

Email: Valentina_sport@ukr.net
Citation:

Todorova Valentyna Georgievna, Petro Fedorovich Rybalko, Oksan Yakivna Dubynska, Oleksandr Serhiyovich Khomenko, Gvozdetska Svitlana Volodymyrivna, Andrii Dmytrovich Krasilov, Yevtushenko Yevhen Hryhorovych. (2021). Mma Exercises in Physical Education of 17-18-YearOld Students. Propósitos y Representaciones, 9 (SPE3), e1162. Doi: http://dx.doi.org/10.20511/pyr2021.v9nSPE3.1162 


\begin{abstract}
In modern science there is a permanent search for new effective forms of organization of the educational process in physical training at higher education institutions of different orientation. The article presents a solution of the actual scientific and practical task of improving the level of physical fitness of students and increasing the readiness of young people of military age to fulfill their national service obligation and advancement of the content of physical education in agrarian institutions of higher education by means of the program of sectional classes using the means of MMA. Due to the conducted research, for the first time, the structure and content of the program of sectional classes with the priority use of means of MMA all-around in physical education of students of institutions of higher education has been scientifically substantiated; the effectiveness of the use of means of military sports all-around for students of agricultural institutions of higher education was determined by indicators of their physical condition, physical development, functional and psychological state, physical fitness. The effectiveness of the author's program is confirmed by the improvement of functional capabilities, normalization of physical condition, enhancement of the level of physical fitness, increase of interest of young men to engage in physical education and importance of instrumental and terminal values.
\end{abstract}

Keywords: physical fitness, process, sectional classes, double-event, means, methods, improvement.

\title{
Resumen
}

En la ciencia moderna existe una búsqueda permanente de nuevas formas efectivas de organización del proceso educativo en el entrenamiento físico en las instituciones de educación superior de diferente orientación. El artículo presenta una solución de la tarea científica y práctica real de mejorar el nivel de aptitud física de los estudiantes y aumentar la preparación de los jóvenes en edad militar para cumplir con su obligación de servicio nacional y el avance del contenido de la educación física en las instituciones agrarias de nivel superior. educación mediante el programa de clases seccionales utilizando los medios de MMA. Debido a la investigación realizada, por primera vez se ha fundamentado científicamente la estructura y contenido del programa de clases seccionales con el uso prioritario de medios de MMA integral en la educación física de estudiantes de instituciones de educación superior; la efectividad del uso de medios de deportes militares en todos los aspectos para los estudiantes de instituciones agrícolas de educación superior se determinó mediante indicadores de su condición física, desarrollo físico, estado funcional y psicológico, aptitud física. La eficacia del programa del autor se ve confirmada por la mejora de las capacidades funcionales, la normalización de la condición física, la mejora del nivel de aptitud física, el aumento del interés de los hombres jóvenes por participar en la educación física y la importancia de los valores instrumentales y terminales.

Palabras clave: aptitud física, proceso, clases seccionales, doble evento, medios, métodos, mejora.

\section{Introduction.}

In modern science there is a constant search for new effective forms of organization of the educational process in physical training at higher education institutions of different orientation. From this point of view, the issues of substantiation of physical activity norms, the ways of preserving and improving students' health are actual (Ilnytskyy et al., 2018; Konzak \& Bourdeau, 1984).

Different social, political and economic conditions in Ukraine dictate the urgent need to increase the level of readiness of young people to fulfill their patriotic duty and, accordingly, a high level of functional, physical and psycho-emotional preparedness. The topicality of such researches increases due to the scientist's criticism regarding the low level of students' readiness and the lack 
of effective reforms in physical education at universities (Pyecha, 1970; Vertonghen \& Theeboom, 2010).

In recent decades, there has been an increase in scientific research on the development and improvement of methods (programs) for mixed-sportstrainingsand complex combat sports for students, the formation of the normative base of complex combat sports and the improvement of physical training of athletes of the military-sports complex. An effective solvation of this task could be the use of the means (features) of complex combat sports in the physical education of student youth. Moreover, it has applied (practical) and humanistic value (Columbus \& Rice, 1998; Donohue \& Taylor, 1994; Duthie et al., 1978; Egan, 1993).

It should be mentioned that in the scientific literature the main accent is made on the development of the complex combat training programs mostly for qualified athletes $(8,18]$. On the one hand, there is also considerable research on the theoretical and methodological basis of the use of military combat sports and MMA in the Armed Forces Specialist Training System. On the other hand, there was no scientific discussion and substantiation of the use of MMA sport for student groups at higher education institutions (Neto et al., 2013; Pityn et al., 2017; Prystupa et al., 2019).

The analysis of scientific works revealed some contradictions between the level of students' physical preparedness, the readiness of young people of conscript age to perform military duty and the content of physical education at universities. The solution of such kind of contradiction is an urgent scientific challenge that might be overcome through MMA training programs in the physical education of future agrarian professionals.

The purpose of the study is to improve the content of students 'physical education at higher agricultural institutions by the use of MMA sectional classes.

\section{Material \& methods}

Theoretical analysis was used to summarize the data of scientific and methodological literature on topical issues in the field of research. Analysis of documentary materials enabled to study the program-regulatory requirements and documents devoted to physical education of students at higher agricultural institutions, requirements for their preparedness. Sociological methods (surveys, questionnaires) were used to study the motivation of students of different specialties at higher agrarian institutions to be physically active and to exercise. Pedagogical testing enabled to determine the level of students' physical skills and their division by the levels of preparedness. Besides, it enabled to determine those indicators at different stages of the research.

Medical and biological methods (anthropometry, spirometry, the Ruffier functional test, time of heart rate recovery (HR) after 20 squats, method of physical state level estimation according to V. Belov); psychological methods (the «Interlaced lines» test, Jacobs method, the «Number Placement» method, the Munsterberg test, the method of determining the value orientations of $\mathrm{M}$. Rokich) were used to obtain objective empirical data on physical condition, physical development, functional and psychological state of physical fitness of agrarian students.

Pedagogical experiment was aimed at determining the effectiveness of the author's program of section sessions on physical education of students of higher agricultural institutions. The basis of the program was the use of MMA exercises.

Mathematical statistics methods have been used to obtain objective data on the various aspects and collections of digital data in the course of a study at various stages.

In order to solve those tasks within the framework there were measured the indicators of 128 first- and second-year students (17-18 year old) of Sumy National Agrarian University. Among the students there were representatives of the following specialties: construction, veterinary and agronomic. The following indicators were established: features of physical development, functional state, physical fitness and psychophysiological characteristics. Students were also interviewed for motivational priorities and attitudes toward physical education. 
The next stage of research (September 2017 - June 2018) was a parallel comparative pedagogical experiment. It was conducted to test the effectiveness of the MMA section program. At this stage, control and experimental groups were formed. The control group enrolled 16 students aged 17-18 years (only male), and the experimental group - 15 students of the same age (only male). The aim of experiment was to determine the effectiveness of the MMA section program in comparison with the traditional one.

The structure and content of the author's program was based on the requirements represented in special literature on MMA (Donohue \& Taylor, 1994; Egan, 1993; Konzak \& Bourdeau, 1984; Lakes \& Hoyt, 2004). At the same time it was adapted and integrated into the pedagogical experiment. The initial material was composed of the following sections: theoretical and psychological training, technical and tactical training, general and special physical training. The ratio of time allotted to different types of training was as follows:6 hours (5\%) for theoretical and psychological training, 34 hours $(28.2 \%)$ - for technical and tactical, 40 hours $(33.4 \%)$ - for general physical and 40 hours $(33.4 \%)$ - for special physical training.

\section{Results}

On the basis of the analysis of scientific literature and the normative-legislative acts, it was determined that the modern trends of physical education at higher education institutions are the following: the improvement of the quality of organization of physical-fitness, sports, mass, training, educational and extra-curricular activities of students; the use of physical culture features and exercises for all-round development of personality; the search for optimal ways to increase students' motivation for physical education and sports taking into account their motivational priorities during developing physical education programs; the formation of valuable categories of personal physical culture (Fuller, 1988).

Summarizing the data of scientific and methodological literature on the problem of physical education of students at higher agricultural institutions and taking into account the specifics of their educational and professional activity enabled to find out the content of physical education at universities. This requires the formation of vital motor skills necessary for further every day and professional activities; professionally applied orientation of the educational process; development and implementation of appropriate regulatory software, including professional and qualification requirements for future specialists in agrarian specialties (Finkenberg, 1990).

The content of physical education of students at higher agricultural institutions should also be based on the norms of weekly physical activity and taking into account their physical development, functional and psychophysiological state and physical fitness of students-agrarians. That is why there is the need for the development of innovative fitness programs, taking into account the specific educational and professional activities of the agricultural sector specialist; a regulated organization of mass sports events to preserve and promote students 'health and popularization of a healthy lifestyle; the formation of a harmoniously developed personality; the construction of educational process on physical education taking into account students' motivational priorities; creation of adequate material and technical base at higher agrarian institutions; the increase of qualification of teachers and coaches in sport (Duthie et al., 1978).

It was established that the present social and political conditions in our country have intensified the studies on the use of martial arts at universities of various types. Scientists confirm that there is a close relationship between the means of these sports and the patriotic upbringing of personality, along with the improvement of physical fitness and different components of professional physical training of student youth. 
According to the first stage of our research the MMA features and exercises might be used as a solution of the contradiction between the level of students 'physical fitness, the readiness of conscript youth to perform military duty and the content of physical education at universities (Khomenko \& Rybalko, 2018).

The survey has identified the students' interests and motivation to be physically active and to participate in classes during studying at university. It has been established that most students $(56,7 \%)$ have a positive attitude to physical education and sports. The reason for the negative attitude of students was determined by excessive physical activity $(35,1 \%)$ and absence of the exercise which they are interested in $(25,9 \%)$.

It was found that important motives for agrarian students are the following: the improvement of body structure $(33,3 \%)$, the increase of health status $(22,0 \%)$ and the opportunity to communicate with friends $(12,7 \%)$. Besides, we found that $26,3 \%$ of students are interested in MMA exercises during university classes. Some of them $(9,1 \%)$ prefer the exercises connected with fight.

The next stage of the research enabled to determine the level of physical fitness and functional status of students. It has been established that most of them have the average level (Table 1). We took into account such indicators as height and body mass, chest circumference, the level of physical development according to the Kettle index. It was determined that the biological age of the 17-18-year-old students corresponds to their chronological age. According to the Kettle body mass index the students have an average level of physical development (table 2).

Table 1. Functional indicators of $17-18$ year old students $(n=128)$

\begin{tabular}{|c|c|c|c|c|}
\hline Indicators & $\overline{\boldsymbol{x}}$ & $\mathrm{S}$ & $\mathrm{m}$ & $\mathrm{V}$ \\
\hline Heart rate at rest, bpm & 76,35 & 3,78 & 0,39 & 5,32 \\
\hline Systolic bloodpressure, $\mathrm{mmHg}$ & 118,56 & 5,6 & 0,52 & 5,2 \\
\hline Diastolic blood pressure, $\mathrm{mmHg}$ & 74,5 & 6,12 & 0,45 & 8,9 \\
\hline VitalCapacity, ml & 4115,00 & 162,07 & 0,02 & 6,35 \\
\hline $\begin{array}{c}\text { A recovery heart rate after 20 squats in 30 } \\
\text { seconds, bpm }\end{array}$ & 128,7 & 2,74 & 0,07 & 0,12 \\
\hline The Ruffier index & 11,78 & 2,98 & 0,23 & 25,8 \\
\hline
\end{tabular}

It was revealed that the functional indicators of the students are also within the normal range. According to the Ruffier index, the students with a number 11,78 $\pm 2,98$ were below the average level.

According to the method of V. Belov it was found that students have mostly average level of physical state. However, according to the results of determining the level of physical fitness indicators in 9 tests were lower than average level (77 points).

According to the method of M. Rokich it was revealed that the most significant orientations for the agrarian students are important specific and individual values of personal life and interpersonal relationships. At the same time the least significant orientations are acceptance of others, passive and ethical values.

In addition, experimental part of the research proved the effectiveness of implementation of section classes with MMA exercises into the educational process of agrarian students.

During the development of the author's program we have captured the content of the Basic curriculum of physical education for higher education institutions of III - IV level accreditations, as well as a professiogram for the natural-humanitarian group specialties.

The tasks of the author's program with MMA exercises for agrarian students were planning of rational organization of sectional classes and independent activity of students; the increase of the physical fitness level and psychophysiological indicators of students; formation of positive motivation for physical education. 
The experimental factor was the implementation of section classes based on the use of MMA exercises into the content of physical education of Sumy National University.

It was carried out only in agreement with the administration of the University and enabled to realize the right of the students for the variability and independent choice of the content of physical education during studying.

According to the construction of the curriculum and the role of physical education at Sumy National Agrarian University, the section classes with MMA exercises were conducted twice a week.

MMA classes were conducted in a specialized gym individually and in pairs, and sometimes in small groups. During the classes there were used streaming and frontal ways of exercise organization.

The general organization of section sessions corresponded to the recommendations of specialists and included three parts: preparatory (warm-up), main (work out) and final (cool-down). The development of students' physical skills and the studying of new types of exercises and techniques were planned in the main part of the class.

It should be mentioned that MMA classes had different load regimes. That is why we offered different duration of preparatory part (warm-up). But at the same time it was compensated by the greater intensity and focus on the global impact on muscle groups. The main part of the classes was aimed at studying the elements of MMA and repetition of already learn material. Also, the final part of the class was extended in duration. It was connected with the intensity of the main part of the class, because the heart rate during it was high that is why its normalization also required more time (Pityn et al., 2017).

In total, 120 hours of classes were conducted with the students of the control and experimental groups. Sectional classes were conducted twice a week for 8 months, lasting two academic hours for each. The students of the experimental group were given individual explanations and recommendations regarding the use of MMA exercises.

The author's program provided the use of basic pedagogical and specific methods such as verbal (description, story, explanation, conversation, analysis, lecture, commentary, instructions and commands), visual (direct and indirect visualization) and practical (strictly regulated exercise continuous, interval, rhythmical, variable, game, competitive, circle training).

For the students of the experimental group, there were applied two main training regimes:

1) Regime with 130-150 bpm heart rates. In that regime students worked in true steady state, which allows exercising for a long time. Such training improves the body's capabilities, which are the physiological basis of overall endurance (stamina) and physical preparedness;

2) Mixed regime with $150-170 \mathrm{bpm}$ heart rates.

During classes we paid attention to the heart rate - it should be in a range from 60 to $80 \%$ of the maximum, recommended for the age of the students. For the students with higher than average level of physical fitness, there were used section sessions with a total duration of 50-60 minutes and an intensity of $60-70 \%$ of the maximum recommended heart rate. For the students of average level of physical fitness, the duration of the section session was 45-50 minutes with a slightly higher intensity (70-75\% of the maximum). For the students with a low level of physical fitness, the duration was $40-45$ minutes; the intensity was $75-80 \%$ of the maximum according to heart rate.

The MMA session program envisaged three consecutive stages: familiarization (creating an idea about technical action); studying (formation of motor skills) and training (improvement of motor skills). 

exercises:

For the contingent of the experimental group, it was proposed the following sequence of

- $\quad$ studying the position of the grouping in the sitting position, then lying on back;

- $\quad$ practicing a roll in the grouping position, over back and head;

- $\quad$ working out the end positions when falling back (on the back) and to the side;

- $\quad$ practicing pre-emptive hits and kicks while lying on the ground;

- $\quad$ learning to fall consistently from low, medium, high racks;

- $\quad$ learning to fall through a training stick (gym bench, partner);

- $\quad$ practicing a fall in motion in combination with other elements and actions;

- learning to roll over the shoulder from the seat and in motion;

- $\quad$ practicing a fall followed by the rapid adoption of the pre-battle position.

For all MMA technical elements the learning took place in the following order: by sections (with the help of preparatory exercises); overall at a slow pace; in step and run; performing actions after sudden signals and commands with change of direction and speed of movement with overcoming obstacles and other actions.

According to the results of the pedagogical experiment, there were revealed the following changes in the indicators of physical fitness of the students (table 2).

Table 2. Changes of physical fitness indicators of 17-18 year old students during the pedagogical experiment

\begin{tabular}{|c|c|c|c|c|c|c|}
\hline \multirow{4}{*}{ Test } & \multicolumn{6}{|c|}{ Stages of research } \\
\hline & $\begin{array}{c}\text { Before } \\
\text { experimen } \\
t\end{array}$ & $\begin{array}{c}\text { After } \\
\text { experimen } \\
t\end{array}$ & \multirow[t]{2}{*}{$\begin{array}{c}\text { increase } \\
, \%\end{array}$} & $\begin{array}{c}\text { Before } \\
\text { experimen } \\
t\end{array}$ & $\begin{array}{c}\text { After } \\
\text { experimen } \\
t\end{array}$ & \multirow[t]{2}{*}{$\begin{array}{c}\text { increase, } \\
\%\end{array}$} \\
\hline & indicator & indicator & & indicator & indicator & \\
\hline & \multicolumn{3}{|c|}{ Control group $(n=16)$} & \multicolumn{3}{|c|}{ Experimental group $(n=15)$} \\
\hline $\begin{array}{c}\text { 1. Balance } \\
\text { («flamingo»), } \\
\text { number of } \\
\text { attempts }\end{array}$ & 13,1 & $9,2 * * *$ & 44,4 & 12,6 & $7,4 * * *$ & 71,4 \\
\hline $\begin{array}{l}\text { 2. Upper limb } \\
\text { movement time, } \\
\text { seconds }\end{array}$ & 12,9 & 11,5 & 12,2 & 12,6 & $10,4^{*}$ & 21,1 \\
\hline $\begin{array}{l}\text { 3. Long jump, } \\
\text { centimeters }\end{array}$ & 158,7 & 164,5 & 3,6 & 159,1 & $178,9 *$ & 12,4 \\
\hline $\begin{array}{l}\text { 4. Set-ups, } \\
\text { number of times } \\
\text { in } 30 \text { seconds }\end{array}$ & 17,2 & 17,8 & 3,5 & 17,4 & $19,1^{*}$ & 9,8 \\
\hline $\begin{array}{l}\text { 5. Bent arm } \\
\text { hang, seconds }\end{array}$ & 8,2 & 8,8 & 7,3 & 8,4 & $9,2^{*}$ & 9,5 \\
\hline $\begin{array}{l}\text { 6. Shuttle } \\
\text { running } 5 \times 10 \mathrm{~m} \text {, } \\
\text { seconds }\end{array}$ & 14,2 & $13,1 * * *$ & 8,4 & 14,4 & $12,4^{*}$ & 16,1 \\
\hline $\begin{array}{l}\text { 7. High jump, } \\
\text { centimeters }\end{array}$ & 26,7 & 27,8 & 4,1 & 26,4 & $28,1^{*}$ & 6,4 \\
\hline $\begin{array}{l}\text { 8. Hand-held } \\
\text { dynamometry, } \\
\text { kilograms }\end{array}$ & 27,4 & 28,7 & 4,7 & 27,8 & $30,5^{*}$ & 9,7 \\
\hline $\begin{array}{l}\text { 9. Running } 300 \\
0 \mathrm{~m} \text {, minutes }\end{array}$ & 17,8 & 16,9 & 5,3 & 17,4 & 16,5 & 5,4 \\
\hline
\end{tabular}

Notes: * - significant difference between the students of the experimental group before and after the pedagogical experiment at $p \leq 0,05\left(t_{\text {table }}=2,05 ; n=15\right)$;

** - significant difference between the students of experimental $(n=15)$ and control $(n=16)$ groups before and after the pedagogical experiment at $\mathrm{p} \leq 0,05\left(\mathrm{t}_{\mathrm{table}}=2,05\right)$; 
*** - significant difference between the students of the experimental group before and after the pedagogical experiment at $\mathrm{p} \leq 0,05\left(\mathrm{t}_{\text {table }}=2,04 ; \mathrm{n}=16\right)$.

Under the influence of the author's program, a significant improvement in the following indicators of functional status was found in the experimental group: heart rate at rest (increase $4,84 \%$ ), vital capacity of lungs (increase 7,65\%), the Ruffier index (increase 23,4\%), heart rate recovery time after 20 squats in 30 seconds (increase $9,81 \%$ ).

According to the $\mathrm{V}$. Belov method, the positive influence of the author's program on the following indicators was determined: rate recovery time after 20 squats in 30 seconds, a long jump, bent arm hang. Moreover, the number of colds during the year decreased (table 3).

Table 3. Express assessment of the level of physical state of 17-18 year old students by V. Belov method

\begin{tabular}{|c|l|c|c|c|}
\hline \multirow{2}{*}{ Level of physical state } & \multicolumn{4}{|c|}{ Stages of research } \\
\cline { 2 - 5 } & initial & ending & initial & ending \\
\cline { 2 - 5 } & Control group $(\mathrm{n}=16)$ & Experimental group $(\mathrm{n}=15)$ \\
\hline Very low & 3 & 2 & 2 & 1 \\
\hline Low & 4 & 3 & 3 & 1 \\
\hline Average & 9 & 11 & 10 & 2 \\
\hline High & - & - & - & - \\
\hline Very high & - & - & - & \\
\hline
\end{tabular}

Under the influence of the author's program, at the end of the pedagogical experiment, $13,4 \%$ of agrarian students had a high level of physical state.

During the experimental study, the motives and interests of the students in experimental group in physical education and sports also have changed. At the beginning the most significant motives were communication with friends (20\%), respect among classmates (20\%), avoidance of possible troubles made by the teacher $(26,7 \%)$. At the end of the research the following motives were the most important for the youth: improving the body shape $(26,7 \%)$, curiosity $(26,7 \%)$, improving health and improving motor performance (20\% for each).

Testing the level of physical fitness by 9 tests allowed to establish significant increasing the experimental group in comparison with the control group in the following indicators: speed $(8,98 \%)$, explosive force $(8,79 \%)$, strength endurance in «Set-ups test» $(6,29 \%)$, strength endurance on the «Bent arm hang test» $(2,21 \%)$, general endurance $(7,73 \%)$, static strength $(4,79 \%)$.

\section{Discussion}

The current trends in improving the structure and content of physical education at higher education institutions indicate the need to take into account the professional and applied physical training of students and the existing challenges of social and political development of the country. Specialists of physical education are assured that it is important to consider the personal needs and motivation of students, as well as to use the varied content of physical education, and improve the defense capacity of student youth.

Generalized requirements for students 'professional preparedness include the acquisition of skills in various sports and physical activities, obtaining competencies in the use of physical culture and sports, the development of motivation for systematic training and improving the level of health, the formation of appropriate self-orientation values, increasing physical and psychological readiness to perform different activities (Madden, 1995; Pyecha, 1970). 
The main motivational priorities of 17-18-year-old agrarian students in the process of physical education are improvement of body shape $(33,3 \%)$ and improvement of health status $(22,0 \%)$. At the same time some values are related to physical and mental health, an active lifestyle, obtaining loyal friends and material stability of life, upbringing, diligence, accuracy and efficiency in affairs (Khomenko \& Rybalko, 2018; Konzak \& Bourdeau, 1984).

It should be mentioned that the majority of students has positive attitude to physical education and sports at university $(56,7 \%)$. However, there are some negative factors such as overloading during physical culture classes $(35,1 \%)$, lack of interesting exercises $(25,9 \%)$, subjective estimation of their own level of physical fitness $(22,1 \%$ of respondents rated it as «satisfactory» and 16,2\% - «poor»).

Testing of physical fitness 17-18 year old agrarian students indicated directions for further improvement.

For the most part, students had lower than average levels by the method of V. Belov (77 points). It is characterized by the following results of tests: «Balance («flamingo»)» 7 errors in one attempt (11 points, average level); «Long jump» - 175,4 cm (9 points, average); «High Jump» $25,8 \mathrm{~cm}$ (7 points, below average); «Hand-held dynamometry» (7 points, below average); «Upper limb movement time» $-12,7$ seconds ( 7 points, below average); «Bent arm hang» $-8,7$ seconds ( 7 points, below average); «Set-ups» - 17 times in 30 seconds ( 7 points, lower than the average level); «3000m Run»-17,7 minutes (11 points, average); «Shuttle Run 5x10 m»-14,7 seconds (11 points, average level).

At the same time there search of functional indicators and physical development of students (heart rate, systolic blood pressure, diastolic blood pressure, vital capacity of the lungs) showed that the largest fluctuations were observed in the Ruffier index, which indicated their compliance with the general dynamics.

According to the results of the researches, the data of other scientists were confirmed and new theoretical provisions were disclosed, in particular: the level of motor activity of student youth; motivation of students to exercise during physical culture classes; peculiarities of professional training of students of different specialties.

There was developed information about the modern requirements for students' readiness and the tendency of physical education of higher education institutions.

It was improved scientific data on motivation of students of higher education institutions to physical education; the structure and content of physical education at higher education institutions; the efficiency of the use of MMA exercises and its influence on the indicators of students' physical fitness, physical development and psychological state.

The new scientific data is the substantiation of the structure and content of the program of section classes using MMA exercises in the physical education of agrarian students.

\section{Conclusions}

1. The program of section classes using MMA exercises for students was substantiated. Its peculiarities are the orientation of technical and tactical preparation for the study of appropriate motor skills and practical development of tactical elements and their combinations in MMA. At the same time, general physical training was aimed at the use of MMA exercises to improve students' health and physical fitness, develop motor skills and positively influence the motivation to exercise. Theoretical and psychological training included individual discussions with students about proving the importance and necessity of using MMA exercises in physical education as a component of professionally applied physical training and psychological readiness to defend the Motherland. 
2. Implementation of the author's program of section classes with MMA exercises proved its effectiveness in the following groups of indicators:

- improvement of functional opportunities, normalization of physical state. In particular, the students of the experimental group in comparison with the control improved the heart rate at rest by $4,83 \%$, the vital capacity- by $7,25 \%$, the heart rate recovery time after 20 squats in 30 seconds- by $10,02 \%$, the Ruffier index - by $18,05 \%, \mathrm{p} \leq 0,05$;

- increase in the level of physical fitness in the experimental group in comparison with the control was the following: by tests for determination of balance-27,02\%, speed $-8,98 \%$, explosive force $-8,79 \%$, force endurance (by the test «Set-ups» $-6,29 \%$, in the test «Bent arm hang» $-2,21 \%$ ), general endurance $-7,73 \%$, static strength $-4,97 \%$ from the initial level, $p \leq 0,05$;

- increase of the interest in physical education and value orientations. Dominant values for students are active lifestyle, health and friendship, upbringing, accuracy and responsibility.

\section{Conflict of interests}

The authors declare that there is no conflict of interests.

\section{References}

Columbus, P. J., \& Rice, D. (1998). Phenomenological meaning of martial arts participation. Journal of Sport Behavior, 21, 16-30.

Donohue, J., Taylor, K. (1994). The classification of the fighting arts. J Asian Mart Art; 3(4):10-37.

Duthie, R. B., Hope, L., \& Barker, D.G. (1978). Selected personality traits of martial artists as measured by the adjective checklist. Journal of Perceptual and Motor Skills 47, 71-76.

Egan, M. A. (1993). The effects of martial arts training on self-acceptance and anger reactivity with young adults. ProQuest Dissertation Abstracts No. AAC 9239036.

Finkenberg, M. E. (1990). Effect of participation in Tae Kwon Do on college women's selfconcept. Journal of Perceptual and Motor Skills, 71, 891-894.

Fuller, J. R. (1988). Martial arts and psychological health. British Journal of Medical Psychology, $61,317-328$

Ilnytskyy, I., Okopnyy, A., Palatnyy, A., Pityn, M., Kyselytsia, O., Zoriy, Y. (2018). Use of boxing to improve the physical education content in lyceums with intensive military and physical training. Journal of Physical Education and Sport (JPES), 18 (1), Art 35, pp. 262-269, doi:10.7752/jpes.2018.01035

Khomenko, O. S., Rybalko, P. F. (2018). Efficiency of the use of complex military sports in the physical education of students of agricultural specialties. Sports Science of Ukraine.; 4: 5158. URL: http: //sportscience.ldufk.edu.ua/index.php/snu/article/view/780

Konzak, B. \& Bourdeau, F. (1984). Martial Arts Training and Mental Health: An exercise in selfhelp. Canada's Mental Health 32, 2-8.

Lakes, K. D., \& Hoyt, W. T. (2004). Promoting self-regulation through school-based martial arts training. Applied Developmental Psychology, 25, 283-302.

Loza, T. O., Khomenko, O. S. (2016). Motivation of agrarian students to exercise in physical culture and sports. Prydniprovsky Sports Newsletter; 3: 115-118.

Madden, M. E. (1995). Perceived vulnerability and control of martial arts and physical fitness students. Journal of Perceptual and Motor Skills, 80, 899-910.

Neto, O. P., Marzullo, A. C. D. M., Bolander, R. P., \& Bir, C. A. (2013). Martial arts striking hand peak acceleration, accuracy and consistency. European Journal of Sport Science, 13(6), 653658. doi:10.1080/17461391.2013.775350

Pityn, M., Okopnyy, A., Tyravska, O., Hutsul, N., Ilnytsky, I. (2017). Dynamic of indexes of technical and tactical actions of qualified kickboxer individual fighting style. Journal of 
Physical Education and Sport (JPES). 17 (Supplement issue 3). pp. 1024-1030. doi:10.7752/jpes.2017.s3157

Prystupa, E., Okopnyy, A., Hutsul, N., Khimenes, K., Kotelnyk, A., Hryb, I., Pityn, M. (2019). Development of special physical qualities skilled kickboxers various style of competitive activity. Journal of Physical Education and Sport (JPES), Vol 19 (Supplement issue 2), pp $273-280$

Pyecha, J. (1970). Comparative effects of judo and selected physical education activities on male university freshman personality traits. Research Quarterly, 41, 425-431.

Vertonghen, J., Theeboom, M. (2010). The socio-psychological outcomes of martial arts practice among youth: a review. J Sport Sci Med; 9:528-37.

Zadorozhna, O., Briskin, Y., Perederiy, A., Pityn, M., Stepanchenko, N. (2018). Improving fencers' theoretical training based on the stage reached in their basic development. Ido movement for culture. Journal of Martial Arts Anthropology, Vol. 18, no. 2, pp. 43-47 doi: 10.14589/ido.18.2.6

Zadorozhna, O., Okopnyy, A., Hutsul, N., Kotelnyk, A., Grashchenkova, Z., Perederiy, A., Pityn, M., Svistelnyk, I. (2019). Improving kickboxers' special physical preparedness which accounts for their individual tactical style and technical skills. Journal of Physical Education and Sport, Vol.19 (issue 2), Art 170, pp. 1173 - 1179. DOI:10.7752/jpes.2019.02170

Zadorozhna, O., Briskin, Y., Pityn, M., Smyrnovskyy, S., Semeryak, Z., Khomiak, I., \& Hlukhov, I. (2018). Multi-functional technical devices for improvement and control of athletes' preparedness in martial arts. Sport Mont, 18(1). doi: 10.26773/smj.200202 